\title{
Prediction of consanguinity using human DNA fingerprints
}

\author{
R A WELLS*, B WONKE†, AND S L THEIN* \\ From * the MRC Molecular Haematology Unit, and Nuffield Department of Clinical Medicine, John Radcliffe \\ Hospital, Oxford OX3 9DU; and the Department of Haematology, Whittington Hospital, London N195NF.
}

SUMMARY DNA fingerprinting was performed to verify the pedigree structure of a family under ơ investigation for an unusual case of $\beta$ thalassaemia. A higher than expected proportion of $\vec{\circ}$ hypervariable bands was shared by the proband and his mother, leading to suspicion that the child had been the product of a consanguineous mating. Further analysis of the mother's brother showed that he was almost certainly the proband's father.

Accurate assessment of pedigree structure is of considerable importance in genetic studies. Traditionally blood group, protein, and tissue antigen markers have been used for this purpose. These approaches are limited by virtue of their low individual informativeness and their major application is in the exclusion of paternity.

Over the last few years many sequence variants of human DNA have been described which are detectable as restriction endonuclease fragment length polymorphisms (RFLPs). The advantage of DNA polymorphisms is their virtual limitless number. Recently, a class of DNA probes capable of detecting multiple sequences of highly polymorphic length, known as hypervariable regions (HVRs), has been isolated. Under appropriate hybridisation conditions, multiple HVRs can be detected simultaneously in human DNA to produce a 'DNA fingerprint' that is completely individual specific and shows somatic and germline stability. ${ }^{1}$ The component alleles of these DNA fingerprints are inherited in a Mendelian fashion and are derived from a large number of dispersed autosomal loci. Hence, DNA fingerprints are highly effective for individual indentification and have been successfully used to resolve disputes arising from lack of proof of family relationships. ${ }^{23}$ As another example of this application, we report the use of DNA fingerprinting analysis in the prediction of consanguinity in a family.

\section{Materials and methods}

CASE REPORT

A five year old Asian Indian boy was referred with

Received for publication 7 March 1988.

Revised version accepted for publication 27 April 1988. anaemia and poor growth. He was born in Africa and had been previously admitted to several hospitals with jaundice and anaemia, but had never been transfused. On examination he was pale, mildly icteric, and rather small for his age; he had bifid thumbs, webbed toes, and a palpable spleen. Haematological investigations showed $\mathrm{Hb} 6.5 \mathrm{~g} / \mathrm{dl}$, MCV $85 \mathrm{fl}, \mathrm{MCH} 27 \mathrm{pg}$, and $3 \cdot 2 \%$ reticulocytes. $\mathrm{Hb}$ electrophoresis showed $\mathrm{Hb} \mathrm{A}_{2} 0.5 \%$ with no $\mathrm{Hb} \mathrm{A}$, the rest of the haemoglobin being $\mathrm{Hb} \mathrm{F}$. Globin chain synthesis studies confirmed the absence of $\beta$ chains with an $\alpha$ :non- $\alpha$ globin chain ratio of 0.33. Cytogenetic studies showed a balanced reciprocal translocation between chromosomes 15 and 20. A provisional diagnosis of thalassaemia intermedia with an unassociated chromosomal anomaly was made. The child was thought to be homozygous for $\beta^{\circ}$ thalassaemia or a compound heterozygote for two different $\beta^{\circ}$ thalassaemia mutations. Haematological investigation of the mother showed $\mathrm{Hb} 12.0 \mathrm{~g} / \mathrm{dl}$, MCV $57.5 \mathrm{fl}$, $\mathrm{MCH} 18.9 \mathrm{pg}, \mathrm{Hb} \mathrm{A_{2 }} 6 \%$, and $\mathrm{Hb} \mathrm{F} 2.6 \%$. The father's indices were $\mathrm{Hb} 16 \cdot 1 \mathrm{~g} / \mathrm{dl}$, MCV $86.6 \mathrm{fl}$, $\mathrm{MCH} 30.6 \mathrm{pg}, \mathrm{Hb} \mathrm{A_{2 }} 2 \cdot 2 \%$, and $\mathrm{Hb} \mathrm{F} 0 \cdot 1 \%$. Thus, the mother was heterozygous for $\beta$ thalassaemia but the father was apparently normal and this was confirmed by a $\beta / \alpha$ globin chain synthesis ratio of $0 \cdot 99$. Non-paternity was denied.

In order to obtain a more definitive diagnosis, particularly for genetic counselling purposes, DNA fingerprinting was carried out on all available family members.

DNA ANALYSIS

Genomic DNA was extracted from peripheral leucocytes by standard techniques. From each subject $5 \mu \mathrm{g}$ DNA was digested with HinfI and 
electrophoresed through a $20 \mathrm{~cm} 1.0 \%$ agarose gel at $2 \mathrm{Vcm}^{-1}$ for 46 hours, at which time the $2 \mathrm{~kb}$ molecular weight marker had reached the bottom of the gel. The DNA was transferred to a nylon membrane (Hybond-N, Amersham) and incubated at $37^{\circ} \mathrm{C}$ for three hours in heparin prehybridisation buffer $(3 \times \mathrm{SSC}, 50 \mu \mathrm{g} / \mathrm{ml}$ heparin, $0.2 \%$ SDS, $50 \%$ formamide). Minisatellite probes 33.15 and 33.6 were prepared from single stranded template, as described by Jeffreys et $a l,{ }^{1}$ and the filter was hybridised to each probe in turn by incubation at $37^{\circ} \mathrm{C}$ overnight in heparin hybridisation buffer ( $3 \times \mathrm{SSC}, 200 \mu \mathrm{g} / \mathrm{ml}$ heparin, $0 \cdot 2 \%$ SDS, $50 \%$ formamide, $5 \%$ dextran sulphate) at a concentration of $2 \times 10^{6} \mathrm{cpm} / \mathrm{ml}$. After hybridisation, the membrane was washed at $65^{\circ} \mathrm{C}$ in $1.0 \times \mathrm{SSC} / 0.1 \%$ SDS for 45 minutes, then autoradiographed. Between the two hybridisations, the probe was eluted from the filter by incubating at $45^{\circ} \mathrm{C}$ in $0.4 \mathrm{~mol} / 1 \mathrm{NaOH}$ for 30 minutes and then in $0.2 \mathrm{~mol} / \mathrm{l}$ Tris $\mathrm{pH} 7.5$, $0 \cdot 1 \times \mathrm{SSC}, 0 \cdot 1 \%$ SDS for 30 minutes.

\section{Results}

The confirmation or exclusion by DNA fingerprinting of a reported family relationship is accomplished by comparing the patterns of hypervariable fragments of the child and its putative parents. The figure shows the DNA fingerprints generated by probes 33.15 and 33.6 for the family described.

The mean probability, $x$, that a band present in a subject's DNA fingerprint will occur in the fingerprint of an unrelated subject has been estimated in population studies to be $x=0 \cdot 2 .{ }^{3}$ Thus, a child whose parents are not related to one another will, on average, inherit one half of the bands appearing in its mother's fingerprint as well as half of the onefifth of his father's bands which are shared by chance with the mother, giving a total average band sharing frequency of 0.6 between parent and offspring.

This frequency, $x$, of band sharing in the population is related to the allele frequency, $q$, by the relation $x=2 q-q^{2}$. Where $q$ is small, as is the case for the hypervariable alleles of DNA fingerprints, $x \sim 2 q$, and so for $x=0 \cdot 2, q \sim 0 \cdot 1$.

Under Hardy-Weinberg equilibrium, the probability that an allele present in a subject is shared by that subject's sib is given by the expression $\left(4+5 q-6 q^{2}+q^{3}\right) / 4(2-q)$. Using the approximation $\mathrm{q} \sim 0 \cdot 1$, this gives a frequency of band sharing between sibs of $0 \cdot 69$. Thus, the expected frequency of fingerprint band sharing between second degree relatives (for example, between aunt and nephew) can be calculated as $[(0.69 \times 0.5)+(0.2 \times 0.5)]=0.44$. We have used these expected frequencies of band sharing to analyse the fingerprint data for the family

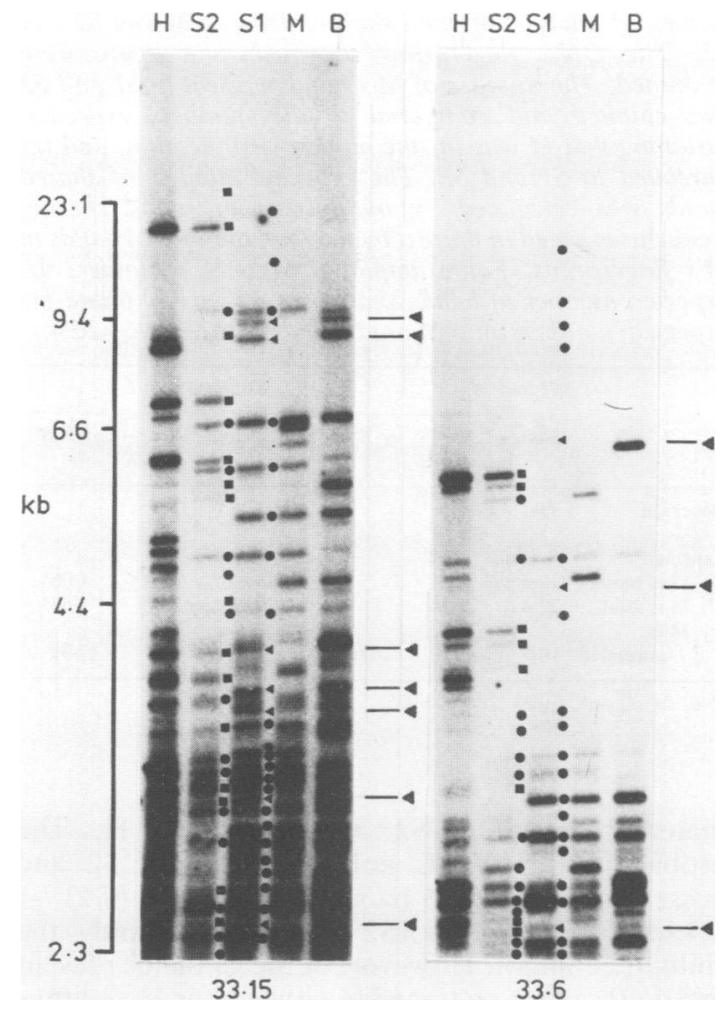

FIGURE Autoradiograph showing the segregation of HinfI fragments containing HVR DNA regions detected by probes 33.15 and 33.6. Lanes: $H=$ husband of $M$, $S 1=$ proband, $S 2=S 1$ 's brother, $M=$ mother of $S 1$ and $S 2$, $B=M$ 's brother. $=$ Maternal bands that could be resolved in $S 1$ and S2. $\square=$ Non-maternal bands that could be resolved in $S 2$. $\$=$ Non-maternal bands that could be resolved in $S 1$ and which were also present in $B$.

under study in this report (table). The fingerprints of S1 (proband) and S2 (his brother) comprise 49 and 50 resolvable bands, respectively. Of the 51 bands present in the fingerprint of $M$, the putative mother, 39 are shared by S1 and 27 by S2. Assuming a binomial distribution, the likelihood that $\mathrm{S} 1$ is not related to $\mathrm{M}$ is $\mathrm{L}(\mathrm{p}=0.2)=\left(\begin{array}{l}51 \\ 39\end{array}\right) 0 \cdot 2^{39} 0 \cdot 8^{12}=6.0 \times 10^{-18}$, and the likelihood of $S 1$ and $M$ being first degree relatives is $\mathrm{L}(\mathrm{p}=0.6)=\left(\begin{array}{c}51 \\ 39\end{array}\right) \quad 0.6^{39} 0.4^{12}=5.9 \times 10^{-3}$, giving odds of $9.9 \times 10^{14}$ to one in favour of a first degree relationship. Similarly, for S2, the odds are $4.5 \times 10^{5}$ to one in favour of a first degree relationship with $M$. Hence, it is highly likely that $M$ is the mother of S1 and S2.

To establish the paternity of $\mathrm{S} 1$ and $\mathrm{S} 2$ we compared the patterns of DNA fingerprints in S1 and S2 with H, M's husband. All the 23 non- 
TABLE $\chi^{2}$ analysis of band sharing between $M$ and S1 and S2. The DNA fingerprints shown in the figure were examined. The number of M's bands present in S1 and S2 was counted and compared to the numbers expected, assuming that $M$ was (a) the mother, (b) the aunt, and (c) unrelated to $S 1$ and $S 2$. The expected number of shared bands was calculated by multiplying the band sharing frequencies stated in the text by the total number of bands in $M$ 's fingerprints. For example, if $M$ is S1's mother, the expected number of bands shared is $51 \times 0.6=30.6$ and the expected number of unshared bands is $51-30 \cdot 6=20 \cdot 4$.

\begin{tabular}{|c|c|c|c|c|c|c|}
\hline & \multicolumn{3}{|c|}{$S 1$ and $M$} & \multicolumn{3}{|c|}{$S 2$ and $M$} \\
\hline & Shared & $\begin{array}{l}\text { Not } \\
\text { shared }\end{array}$ & $x^{2} 1 d f$ & Shared & $\begin{array}{l}\text { Not } \\
\text { shared }\end{array}$ & $x^{2} 1 d f$ \\
\hline Observed & 39 & 12 & & 27 & 24 & \\
\hline $\begin{array}{l}\text { Expected } \\
\text { (a) } M \text { is mother } \\
\text { (b) } M \text { is aunt } \\
\text { (c) } M \text { is }\end{array}$ & $\begin{array}{l}30 \cdot 6 \\
22 \cdot 4 \\
\\
10 \cdot 2\end{array}$ & $\begin{array}{l}20.4 \\
28.6 \\
\\
40.8\end{array}$ & $\begin{array}{c}5 \cdot 76 \dagger \\
21 \cdot 9 \ddagger \\
\end{array}$ & $\begin{array}{l}30 \cdot 6 \\
22 \cdot 4 \\
\\
10 \cdot 2\end{array}$ & $\begin{array}{l}20.4 \\
28 \cdot 6 \\
\\
40 \cdot 8\end{array}$ & $\begin{array}{c}1.06^{*} \\
1.68^{*} \\
\\
17.3 \pm\end{array}$ \\
\hline
\end{tabular}

*Not significant, $\nmid \mathrm{p}<0.02, \neq \mathrm{p}<0.005$.

maternal bands in $\mathrm{S} 2$ are present in $\mathrm{H}$. The probability that $\mathrm{H}$ is not the father of $\mathrm{S} 2$ and possesses all these 23 bands by chance is $(0 \cdot 2)^{23}=$ $8.4 \times 10^{-17}$. Therefore, S2 is almost certainly the child of $\mathrm{H}$ and $\mathrm{M}$. However, of the 49 bands present in $\mathrm{S} 1,10$ cannot be traced to either $\mathrm{M}$ or $\mathrm{H}$ and thus the reported family relationship is false. Of the 51 bands that can be resolved in M's fingerprint, 27 are shared with S2. This degree of band sharing is consistent with a first $\left(\chi^{2}=1.06,1 \mathrm{df}, \mathrm{p}>0.2\right)$ or a second $\left(\chi^{2}=1 \cdot 68,1 \mathrm{df}, \mathrm{p}>0 \cdot 2\right)$ degree relationship, but not with unrelatedness $\left(\chi^{2}=17 \cdot 3,1 \mathrm{df}, \mathrm{p}<0 \cdot 005\right)$. S1 shares 39 of the 51 bands present in M's fingerprint. The expected number of shared bands if $S 1$ is a first degree relative of $M$ is 30.6 , so the number of shared bands between $S 1$ and $M$ is significantly higher than would be expected even for a first degree relationship $\left(\chi^{2}=5 \cdot 76,1 \mathrm{df}, \mathrm{p}<0.02\right)$, and suggests that the father of S1 may be related to $M$. Examination of the DNA fingerprints showed that all the 10 non-maternal bands in S1's fingerprint were present in M's brother, B. The probability that $B$ is unrelated to $S 1$ but happens to share these bands is $(0.2)^{10}=1 \times 10^{-7}$. If, however, some other male relative of $M$ shares these 10 bands with $B$, then that relative could equally be the father of $S 1$. The probability of a sib of $B$ sharing these 10 bands is $(0 \cdot 69)^{10}=0 \cdot 025$. We therefore conclude that the true parents of $\mathrm{S} 1$ are $\mathrm{M}$ and $\mathrm{B}$. Haematological investigations showed that $\mathrm{B}$ is heterozygous for $\beta \stackrel{\overrightarrow{\vec{S}}}{\overrightarrow{\mathrm{s}}}$ thalassaemia which would explain the phenotype of $\bar{C}$ homozygous $\beta$ thalassaemia in S1.

After completion of the studies, $M$ volunteered that her brother, B, was the true father of her son, S1.

\section{Discussion}

DNA fingerprinting is a robust technique which allows positive determination of paternity with a high degree of certainty. In this family it has permitted the detection of consanguinity within a î nuclear family. This use of DNA fingerprinting is unlikely, however, to be universally applicable in the detection of incest because of the variance of 8 parent-offspring band sharing, which will sometimes obscure consanguinity. In this case, S1's unusual clinical phenotype, combined with his very high degree of band sharing with his mother, $\mathrm{M}$, led us to suspect incest. Had the band sharing between $M$ and her brother, B, been slightly lower, and had S1 shared 37 of M's 51 bands instead of 39, then the observations would have been within the bounds of what might be expected for a first degree relationship $\left(\chi^{2}=3.35,1 \mathrm{df}, \mathrm{p}>0.05\right)$. In such a case, and in the absence of clinical clues, the possibility of consanguinity might go unsuspected. Thus, this case must be regarded as anecdotal, and we do not wish to suggest that DNA fingerprinting with these two probes alone will detect consanguinity in all cases.

We are grateful to Liz Rose for preparation of the manuscript, Carolyn Hesketh for expert technical help, and Professor A J Jeffreys, Dr J M Old, and Dr S T Reeders for advice. We thank Professor A J Jeffreys for the use of the probes 33.6 and 33.15 (both subjected to patent application). Professor Sir David Weatherall gave much valued encouragement and support. RAW is a Rhodes Scholar and SLT is a Wellcome Senior Research Fellow in Clinical Science.

\footnotetext{
References

${ }^{1}$ Jeffreys AJ, Wilson $\mathrm{V}$, Thein SL. Individual-specific 'fingerprints' of human DNA. Nature 1985;317:76-9.

2 Gill P, Jeffreys AJ, Werrett DJ. Forensic applications of DNA 'fingerprints'. Nature 1985;318:577-9.

3 Jeffreys AJ, Brookfield JFY, Semeonoff R. Positive identification of an immigration test-case using human DNA fingerprints. Nature 1985;317:818-9.
}

Correspondence and requests for reprints to $\operatorname{Dr} \mathrm{R} A$ Wells, MRC Molecular Haematology Unit, John Radcliffe Hospital, Headington, Oxford OX3 9DU. 